Only Unpaid Labour Force? Women's and Girls' Work and Property in Family Business in Early Modern Italy (Turin $18^{\text {th }}$ century)

\begin{abstract}
This paper aims to investigate the nature of the women's contribution in family businesses in eighteenth-century Turin. Specifically, it discusses the reliability of the notion of unpaid work; it suggests that the latter is a too ambiguous concept and that some kind of distinction which clarifies the role played by each family member should be introduced. Economic and labour relationships between the partners or between the head of the household and other women of the family network were complicated by the presence of the female's personal property, and especially by the dowry. Married women invested in the family business their dowry or, alternatively, they used it in order to set up and run an independent economic activity or to buy a set of tools that enabled them to work autonomously. Widows (mothers or mothers-in-law) did the same. Women therefore were workers and owners at the same time. Their economic contribution to the household was based on an intricate mixture of physical work and property, and precisely for this reason they cannot be considered as an unpaid labour force. Finally, the paper shows that property gave the women the bargaining power necessary to negotiate their position in the household or to obtain some kind of help or support.
\end{abstract}

Keywords: Unpaid Work; Women Work; Family Business; Dowry; Bargaining Power

\title{
Manuscript $^{1}$
}

\section{Introduction}

This paper aims to investigate the role of women - mothers, wives and daughters - in family businesses, craft shops and retail or trade in Turin in the eighteenth century. At the same time, it aims to discuss the nature of their work and its impact on family relationships. In classical works on the role of wives and relatives in family business, Christine Delphy and

1 Abbreviations : AST $=$ Archivio di Stato di Torino; ASCT=Archivio Storico del Comune di Torino 
Diane Leonard (1992) made use of the notion of "unpaid work" as a specific methodological tool for studying economic and social relations among members of contemporary Western households. According to their research, unpaid work refers to work performed by women and children - and others dependants living under the same roof - in and for the household. Unpaid work brings together domestic work carried out by women as caregivers and is directed towards the well-being of family members and the maintenance of the house. Yet it refers to "emotional, sexual and reproductive labour" of wives (Delphy \& Leonard, 1992, p. 23). In addition, unpaid work refers to the direct and informal contribution of family members in workshops, retails, farms or other family businesses ${ }^{2}$. In Delphy and Leonard's approach, unpaid work is supplied within the framework of a particular relationship based on the predominance of the head of the household (namely, the husband, or more generally an adult male) over his "dependants" (his wife, children, eventual cohabitant kin, servants, etc.). The husband (or the father) exploits the work of his dependants and owns the product of their work; on the contrary, wives, daughters and sons neither own their labour force nor their production and, as a consequence, they are unpaid.

Even though the notion of unpaid work has been forged and used mostly in reference to contemporary societies, the topic is not unfamiliar to scholars studying pre-industrial societies. According to the pioneering work by Alice Clark (1919), the "family industry" was made up of parents, children, servants and apprentices, all working for the family workshop or trade. In addition, in the wake of the research undertaken by Natalie Zemon Davis (1986) about "married women as unpaid artisans" in sixteenth-century Lyon, the literature has pointed out that women were active participants in family businesses, in farms, as well as in urban shops or retails, and that widows were able to continue their husband's craft or shop because they had worked alongside him all their life (Owen Hughes, 1979; Hanawalt, 1986; Musgrave, 1993; Groppi, 1996; Fauve-Chamoux, 2001; Hafter, 2003; Simonton, 2005; Lanza, 2009). Although there is general agreement about the crucial role of the work performed by women and children in Old Regime family businesses, several points need to be better analysed. Firstly, researchers have not yet really inquired into the nature of this female

\footnotetext{
2 In recent years, many scholars employed the notion of unpaid work; some of them emphasised unpaid work such as various caregivers' tasks, domestic work, childrearing and care given to ill and weak members of the family (Addabbo, Arrizzabalaga, Borderías \& Owens, 2010). Other research refers mostly to work performed by women and other family members in the family business (Phillips, 2008).
} 
economic contribution: was the work performed by wives, daughters and other female members of the family in the family business only "unpaid work"? Was it always an expression of the exploitation of the labour force by the head of the family? This paper aims to call into question the notion of unpaid work in pre-industrial Turin taking into account the role of women's property in labour dynamics. According to Christine Delphy, the exploitation of women's labour by the head of the household was possible because in Western Europe married women did not have access to the ownership of the means of production and because the practice of inheritance did not allow married women to own property (Delphy, 1998). This was true at least in French society, after the Second World War; but what about Old Regime societies? How did relations of production change if women brought their assets into the family business?

In the last 15 years, research - especially Italian historiography - pointed out that preindustrial societies were dominated by a strong ideological and cultural model, based on a patriarchal family headed by the pater familias, husband and father responsible for the wellbeing of all the members of the household (Frigo, 1985; Ago, 2001). This cultural construction valorised only the patrilineal transmission of the family name and assets and the role of agnatic lineage. Of course these mechanisms existed in families, but were not exclusive. Indeed, under "the umbrella of patriarchy", women had assets and property as well as income from work, and all these conferred them some kind of negotiation power in relation to (and despite of) the patriarchal model (D'Amelia, 1993; Ago, 1995; Groppi, 1996; Ago, 1996; Ago \& Borello, 2008). Yet recent research has pointed out that, in contemporary developing countries, women's property and its social acknowledgement enhances women's agency, since it gives them influence over family economic decisions and over society, and finally contributes to the reduction of inequalities among sexes (Agarwal, 1994; Sen, 1999). Despite the importance of these studies, research on the history of the family has seldom taken into account the connections between property and work and explored how this link could affect the nature of the economic relations among partners and among the members of the household. This point in particular sheds light on the ambiguity of the notion of unpaid work. Of course, this paper does not intend to put under discussion the unpaid housework performed by women, such as cooking, washing, child rearing, and family member caring. These kinds of activities have always been performed by women and, although often covered 
by an emotional language, they represent real work, yet always unpaid, taken for granted by the men and also by the women of the household (Delphy \& Leonard, 1992, p. 75-89). Rather, in this paper I suggest that the notion of unpaid work refers to a specific situation and context, while, in eighteenth-century Turin among the middle and lower classes, the economic and labour relationships among the members of the family were complicated by the presence of women's property, and especially by the dowry, the most important female asset. Of course some women were un unpaid labour force: unmarried daughters, for example, performed work in the family business without receiving a wage and without having other negotiation power. But, on the contrary, wives and widows had their dowry and thanks to this they owned the whole or a portion of the family business or they set up and ran independent economic activities. In other terms, women invested their assets in some kind of business and, as a consequence, they were involved in it as workers and owners at the same time. This changes their position and, in some respect, their status towards the head of the family. In this context, female work and property have a political meaning insofar as they allow a crossover of descriptions of female/male relations in respect of a dominant/subordinate relationship. In addition, this paper suggests that women's property gave them bargaining power in order to negotiate their position face to the other members of the family, or their well-being, help and assistance for the present and the future.

The paper is organised as follows. The first section (2) provides evidence of the importance of kinship ties in family workshops and retails, in eighteenth-century Turin. At the same time, it shows that girls and women were mostly a hidden labour force compared to male labour force. The central part of the paper (sections 3 to 5) investigates the nature of the labour contribution of wives and widows in economic activities. Sections 3 and 4 highlight the role of the dowry in the family business and seeks to explain how this impacted on the economic relations between the partners and among mothers/mothers-in-law and the daughter's family. Section 5 focuses on female entrepreneurs and provides further evidence of the fact that, among artisanal and commercial groups, married women were not an unpaid labour force because of their double statute of workers and owners. Finally, section 6 is consecrated to the daughters and points out their crucial role as unpaid labour force in family or mother's businesses. At the same time, it shows that even in this situation, the female property affected the nature of this labour relationship: daughters inherited their mother's 
business and tools while, on the other hand, thanks to this, mothers could negotiate for themselves care and assistance in old age.

\section{Discovering female labour force in the family business}

From the end of the sixteenth century Turin was the capital of the Duchy of Savoy and, from 1713, of the Kingdom of Sardinia. It was a medium-sized city, and its population fluctuated between 58000 inhabitants in 1750 to 76700 inhabitants in 1796 (Castiglioni, 1862). Turin was the city where the royal court, aristocratic families and wealthy merchants lived. Service activities of various levels of prestige and rank played an important role in the local labour market: according to the population census carried out in 1802, 42 per cent of the working female population (aged 15 and over) and more than 38 per cent of the working male population were employed in services (such as domestics, waiters and waitresses, cooks, coachmen, grooms, porters, laundresses and ironers). At the same time, Turin had a strong artisanal and manufacturing tradition supported by important public investments. In 1802, about 33 per cent of women with a job and 38 per cent of men with a job worked in crafts. They mostly produced and sold luxury goods to the upper classes, from the aristocracy at the royal court to the wealthy merchants and bankers, from the religious hierarchies to the army. Taking inspiration from the principles of mercantilism developed by Colbert in France, the king of Sardinia and his ministers pursued a policy that aimed to support silk activities. Important investments were made in the production of silk yarns - mostly concentrated in the Piedmontese countryside and exported all over Europe - and in silk manufacturing, concentrated in the city (Chicco, 1995; 2002). Artisans were moreover concentrated in silk manufacturing (spinners, weavers, dyers, ribbon-makers, sock-makers, bonnet-makers, embroiderers, button-makers, upholsterers) or in preparing cloths and fashion accessories (tailors, seamstresses, shoemakers, glove-makers, furriers). Others were involved in manufacturing and selling metal or wooden items (jewellers and goldsmiths, smiths, armourers, braziers, potters, carpenters, wainwrights). Finally, several produced and sold foodstuffs, spirits and wine. Organisation of artisanal work varied. Near to the royal manufactures (namely, the glass factory, the royal printing press, the tobacco factory) that employed several journeymen, there was a multitude of artisans working at home (chamberlains) on their own or for merchant-bankers controlling the production by the 
cottage system, and numerous small- and medium-sized shops. The following table, based on a census of workshops carried out in 1792, lists some of the most important craft activities, the number of shops existing in the city and their average $\operatorname{size}^{3}$. The census provides information for 60 crafts (22 of which were organised in guilds, "università").

Tab. 1 Crafts in Turin according to the workshop census of 1792

\begin{tabular}{|c|c|c|c|}
\hline 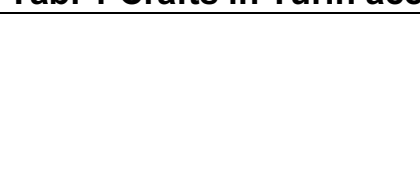 & $\begin{array}{l}\text { n. of } \\
\text { workshops }\end{array}$ & $\begin{array}{l}\text { \% on the } \\
\text { total } \\
\text { number of } \\
\text { workshops }\end{array}$ & $\begin{array}{l}\text { average number } \\
\text { of workers } \\
\text { (masters } \\
\text { included) }\end{array}$ \\
\hline silk weavers & 227 & 9,2 & 4,3 \\
\hline shoemakers & 219 & 8,8 & 6,5 \\
\hline spirit-makers & 134 & 5,4 & 3,1 \\
\hline carpenters & 113 & 4,6 & 4,6 \\
\hline wig-makers & 92 & 3,7 & 3,9 \\
\hline bakers & 86 & 3,5 & 6,4 \\
\hline $\begin{array}{l}\text { ribbon-makers and } \\
\text { trimming-makers }\end{array}$ & 81 & 3,3 & 2,7 \\
\hline barbers & 66 & 2,7 & 3 \\
\hline blacksmiths & 63 & 2,5 & 4 \\
\hline jewellers and goldsmiths & 46 & 1,9 & 4,7 \\
\hline silk socks-makers & 33 & 1,3 & 8 \\
\hline mattress-makers & 28 & 1,1 & 2,7 \\
\hline barrel and basket-makers & 27 & 1,1 & 1 \\
\hline $\begin{array}{l}\text { leathers goods and glove- } \\
\text { makers }\end{array}$ & 21 & 0,8 & 3,7 \\
\hline bonnet-makers & 19 & 0,8 & 8,1 \\
\hline braziers & 14 & 0,6 & 4,3 \\
\hline button-makers & 7 & 0,3 & 2,7 \\
\hline $\begin{array}{l}\text { total number of } \\
\text { workshops recorded in } \\
\text { the census }\end{array}$ & 2477 & 100 & \\
\hline
\end{tabular}

In this economic system, work by members of the family was indispensable. A look at the census of 1792 offers evidence of the importance of kinship ties. Sons, sons-in-law, brothers

3 AST, I sez., Commercio, II add., Magistrato del Consolato, mazzo 2, Volume contente li nomi, cognomi e patria de' mastri e padroni e de' loro rispettivi lavoranti ed apprendizzi delli arti e mestieri, 1792. 
and nephews of the master were recorded as apprentices, journeymen or associates in the majority of crafts. Gio Batta Boretto, master shoemaker, stated that his workshop was composed of his son, Giuseppe, and three journeymen/apprentices. Similarly, Gian Battista Reondo, master ribbon-maker, ran his business with the help of his two sons, Francesco and Agostino (together with Lorenzo Martini, a labourer). On the other hand, Giuseppe Turletti, master silk weaver, worked with his two brothers, while Gaspare and Antonio Gerard, were brothers and associates in a jewellers' that also included three labourers. Other kinship ties are also represented in this census, mostly nephews and sons-in-law of the master. Francesco Dionisio, spirit-maker, got help from Pietro Antonio, a nephew, and another journeyman, while Carlo Germano, master wig-maker, worked with his son-in-law and four labourers.

What about women? In 1792, 76 widows headed a workshop in a variety of crafts: they were bakers (18), silk weavers (12), shoemakers (9), spirit-makers (5), food retailers (5), blacksmiths (4) and jewellers (4). On the contrary, data are not so explicit if we want to focus specifically on wives, siblings and daughters of the masters. Only a few meaningful cases have been recorded. Among silk weavers, in the workshop of Giuliano Mariano, 13 journeymen and apprentices worked together with Orsola Mariano, the wife of Giuliano. Similarly, the shop of Vincenzo Tesio consisted of his daughter Laura and his son Giuseppe and of three other female workers. In the tripery of Francesco Lanza were also registered his wife Giacinta, the couple's two children - a boy (Domenico) and a girl (Genoveffa) - and Domenica Morosso, a servant; on the other hand, Gioanna Carbonina ran the smithy of her husband - composed of three workers - declaring that she worked "on behalf of her husband, who was absent from the Kingdom"4. Despite these cases, the majority of women and girls involved in the family business remain in the shadow. Cross-reference of the names of artisans recorded in 1792 survey with the population census of 1802 provides evidence of the presence of wives, mothers and daughters of the masters, performing work in the shop but not explicitly declared. Bartolomeo Rachetto, for example, a pastry-maker, in 1792 declared that he ran the shop with the help of his son, but ten years later his wife Margherita and a second son were also recorded as pastry-makers with him. Agostino Attis, master silk weaver, in 1792 employed in his workshop four laborers and his son, Agostino Giuseppe, but in the population census his wife, Teresa, was also recorded as a silk weaver (while Agostino

$4 \quad$ All the examples have been taken from the census of turinese workshops carried out in 1792. 
Giuseppe did not state his job). Similarly, Gioacchino Bonetto in 1792 was head of a shop consisting of four journeymen and his son Domenico but, according to the census, his wife Marianna was also employed in silk weaving, together with another son of the couple. On the other hand Giacomo Agazzino, brazier, in 1792 ran a shop selling brass items with the help of his son, while in the census of 1802 he was registered with his wife (also "brazier") and with two workers. In addition, Giacomo's mother lived with the couple and also participated in the work (she too was registered as a brazier).

According to this picture, unpaid work performed by female members for the family business was less visible than that performed by men. This systematic under-evaluation of women's work was rooted in a powerful cultural and ideological model based on the idea that their work - paid as well as unpaid - was socially and economically not valuable. Wives' work especially was considered residual and marginal, compared to the job of the male head of the household. Work was not part of the social identity of women; they were rather expected to act according to their "natural" role, that was to be good mothers and wives. In this sense, female work was a "dutiful contribution" required in order to earn a livelihood and ensure the maintenance of the family, with no social acknowledgement. This also explains why most work done by women was largely unrecorded in Turin as well as in other European societies (Humphries \& Sarasúa, 2012; Zucca Micheletto, 2013). For unpaid work things were complicated by the fact that the job performed by female members in the family workshop was depicted (even by the incumbents) with expressions such as "love for the family" and "filial piety". Women were not workers, they were mostly caregivers, at the service of their family (Hafter, 2007, p. 64-69). Their contribution therefore was not considered a labour worthy of a salary but was masked by the register of the "familial intimacy" (Ago, 1998, p. 107-108 and p. 184-185). In addition, pre-industrial societies did not have a specific juridical approach to the topic, and no law regulated this kind of work: in the words of Natalie Zemon Davis (1986), in sixteenth-century Lyon "even the idea that a salary was due to a wife who helped in the workshop or in the shop was really an unusual situation".

Research in notaries' archives showed that, among the lower classes, testaments were occasions to thank and reward wives and other family members for their care and help in domestic work, for the well-being of other members of the household, as well as in the family business (Bellavitis, 2008; Lumia, 1998). This was a common practice also in Turin. In his 
will dated September 1751, Gio Batta Martinone established that his children, already adults, will inherit 50 livres each, while he named his wife Caterina the sole heir of the whole inheritance. This decision was justified by Gio Batta with the fact that Caterina had always supported the family with her work ("colle opere e travagli"); namely, she always worked hard in the shoemaker's shop and ran it successfully, especially when the health of her husband did not allow him to work ${ }^{5}$. Similarly, Giuseppe Rocchietti, innkeeper, in his will of April 1748, bequeathed to his daughter-in-law Maria Caudiano 300 livres "by way of gratitude and reward for the hard work she has put in until now in order to manage the inn"6 that Giuseppe owned in Turin. Despite this evidence, it is clear that bequests and inheritances were given only as rewards but they cannot be considered wages. At the same time, we cannot conclude that all women were only and always an unpaid workforce. In other terms, we should not be blinded by the power of the cultural and ideological models and we should not confuse the fact that women were invisible in official documents with presumed constant economic weakness and subordination/dependency of women in the household. For this reason, important distinction should be made among the members of the family; the condition of the daughters, for example, was not the same of their mothers or grandmothers. Indeed, if the former performed unpaid jobs this was not the case for wives and widows who, thanks to their dowry had some bargaining power towards the authority of the head of the household. I will analyse the position of daughters further in the paper. Now, the next sections will focus on the condition of wives and widows in two cases: 1) when they perform work as owner (or co-owner) of the family business; 2) when they set up and ran a shop or a retail autonomously.

\section{The dowry in the turinese economic system}

Over the last twenty years Italian historiography has been involved in showing the crucial role played by women's property and assets in the nature of relationships among the members of a household. In the case of women's work, the existence and the importance of women's property have been masked by the rhetorical power of the patriarchal family and of the predominant role accorded to male property and to the patrilinear inheritance system.

\footnotetext{
$5 \quad$ AST, sez. riun., Notai di Torino, vol. 2774, ff. 297r-302v.

6 Ibid., Insinuazione di Torino, a. 1748, 1. 4, ff. 423r-424r.
} 
Despite this, in eighteenth-century Turin, among artisans, shopkeepers, retailers and traders, wives were not only workers in the family business, they were also owners: beyond carrying out concrete work, they contributed to the family workshop with their money or assets. This was possible because in Turin, as in other countries governed by Roman law, upon marriage the bride received a dowry and other eventual goods and assets that she owned. Of course, she brought them into the marriage but she never lost ownership of them, since the marriage settlement was based on the separation of property among partners. Now, it is clear that this specific mechanism could change the quality of economic relations among partners and finally call into question the notion of unpaid work, based on the idea that only the husband/father, as head of the household, owned the means of production and thanks to this he could exploit the work of his dependants.

Ever since the Middle Ages and until at least the nineteenth century, in countries observing Roman law the dowry was indispensable for marriage. The dowry was usually drawn up in a notarial deed - the endowment act - signed by the bride, the groom, and by their parents or relatives ${ }^{7}$. Roughly, in eighteenth-century Turin, the dowry was composed of two parts: a sum of money, usually paid in cash or with a credit note or a private deed, and secondly a set of goods - clothes, linen, furniture, jewels - known as a " marriage trousseau ". The dowry and the trousseau were the personal property of the bride; nevertheless, during marriage, the dowry (but not the trousseau) was managed by the husband for the benefit of the family. In order to ensure repayment, the husband - and his father, if the son was not emancipated from patria potestas - had to secure the dowry on his own estate for the duration of the marriage. Otherwise, the dowry would be entrusted to a third party, a mediator, who invested the sum and paid the legal interest to the couple. The goods of the marriage trousseau were paraphernalia, a juridical category that, according to medieval law, also included female wages coming from her work, personal bequests and inheritance she received from her family or friends. All these assets were known as stradotali and were under the direct control and management of the woman throughout her life (Ago, 1996). Now this is the point: in eighteenth-century Turin, among artisans, retailers and traders, the dowry could change the nature of economic and labour relationships among the members of the family. Indeed,

$7 \quad$ On Turin and Piedmont dowry system see: (Pene Vidari 1980-81; 1983). For Italy, among the abundant literature on the topic, see for example: (Klapisch-Zuber, 1990); (Groppi, 1996); (Calvi \& Chabot, 1998); (Fubini Leuzzi, 1999); (Bellavitis, 2008). 
instead of being a virtual capital, expected to be jealously guarded like a treasure, the dowry was employed in the labour market, in order to open or supply a shop or a retail or to improve it. Women invested their assets in the familial business and this, inevitably, put restrictions on the power of the head of the household.

\section{Dowry and labour relations in familial business}

Even though the dowry was an inalienable estate by law, in eighteenth-century Turin couples could remove this constraint by a juridical procedure and a civil trial known as alienazione dotale. By this, couples obtained the dowry in money and put it to use for the survival and the well-being of their family, reimbursing debts or supplying tools or goods for their craft-shop or retail. Of course, it is likely that couples decided to invest the dowry without passing through the procedure of alienation, and some clues can be found in the notarial deeds of the endowment. Here I am suggesting that the alienations of dowry provide strong evidence of the connections among dowry and family business, a specific point that is often difficult to prove by endowment acts. For this research I used a set of 188 trials for alienations of dowry that took place in Turin at the court of the Giudicatura between 1760 and $1780^{8}$. Couples having recourse to alienation of dowry belonged to all social and professional groups but the majority were artisans, shopkeepers and retailers. After alienation, the dowry, by now in cash and in the hands of the couple, was used for three main goals: 1) to buy a shop or supply a craft-shop or a retail with tools and goods; 2) to pay back money to private creditors or reimburse debts contracted mostly for foodstuff and home rental; 3) to redeem clothes, linens and jewels from the city's pawnshops. These of course were not exclusive and couples utilised the dowry for different purposes simultaneously. Nevertheless, among artisans and retailers the alienation was mostly a mechanism directed at financing an economic activity and allowing access to the local labour market: 42 per cent of families employing immediately the dowry invested it in goods and tools for a shop or a craft shop. Carlo Antonio and Francesca Cardellino, for example, in 1771 used 600 livres of the dowry "in order to buy furniture and linen for beds with the aim of opening an inn". Similarly, Giuseppe and Gioanna Galliano employed their dowry in a common workshop for ribbon

\footnotetext{
8 I studied the dowry system and the alienation of dowry in eighteenth-century Turin in chapters 2 and 3 of my book (Zucca Micheletto, 2014).

$9 \quad$ AST, sez. riun., Notai di Torino, vol. 2756, f. $527 r$.
} 
manufacturing ${ }^{10}$ while Luigi and Maria Grammario in 1772 asked for the dowry of 500 livres in order to pay the wholesaler Antonio Allasia who supplied them 16 calves for the butchery they ran in Turin11. On the other hand, Antonio and Maria Schiardo planned to use the dowry to rent a garden, in order to supply their retail with vegetables12. Some studies maintained that the alienations of dowry prejudiced the wife's property since the husband used the dowry in order to pay off his debts or redress financial loss (Fontaine, 2008). On the contrary, the documentation from Turin provides evidence of the fact that the dowry was used as an important economic and familial resource, and not solely for the benefit of the husband. In most cases, the dowry was invested in a common economic activity, in which both partners were involved and clearly the wife worked actively in the shop or retail. From this perspective therefore it is not surprising that women performed unpaid work: precisely because of her status as owner and worker, the wife did not have the right to a wage, as was the case for her husband. Among the middle and lower classes, therefore, the female contribution to the family business turns out to be an entangled mix of physical work and economic contribution with personal property. In addition, it is clear that these dynamics call into question the definition of unpaid work, since they show that the balance of power among partners was not only and always based on the exploitation of wife's work, nor on the subordination/domination model maintained by the classical notion of unpaid work. The possibility for women of involving property in the family business affected the nature of labour relationships among partners; therefore it opened up some space for negotiation to women and, inevitably, put restrictions on marital power.

Actually, one would argue also that, according to law, during marital life the husband had the right to manage the dowry and, as a consequence, that the investment of the dowry in the family business proved once more the power of his marital authority over his wife. But things were more complicated. Indeed, the law established that alienation could take place only with the explicit agreement of the wife, who was the owner of the dowry. During the procedure, therefore, the judge inquired separately into the real intentions of the wife and he was expected to receive from her an official statement in which she declared that the alienation had been decided of her own free will ("di suo libero e spontaneo volere"). This was a

$10 \quad$ Ibid., vol. 2777 , ff. $290 r-294 r$.

11 Ibid., vol. 2752, ff. 509r-514v

12 Ibid., vol. 2778, ff. 58r-63r. 
symbolic but binding point of the procedure; indeed, if the judge was not able to verify the wife's will, the alienation could not take place. This is for example what happened to Giuseppe Giulio and his wife Teresa Maria. In 1778 their first petition was rejected because at the time of the alienation Teresa Maria was in Como and the judge could not verify her agreement13.

The dynamics described were not typical of eighteenth-century Turin; they were spread all through the cities of the Old Regime Italian peninsula, where a dowry system existed. Research on Genoa, Rome, Florence and Venice has pointed out the role of women's assets in family businesses among middle and lower classes (Owen Hughes, 1975; Ago, 1996; Groppi, 1996; Scardozzi, 1998; Groppi, 2002; Bellavitis, 2008). However, often these mechanisms can be revealed only by clues, as they were mostly informal and did not lead to written deeds; on the contrary, they are well documented for Turin, thanks to the rich and detailed evidence provided by the alienations of dowry preserved in the notarial archives.

The mechanism previously described operated also in other situations. Women's property could change the balance of power not only between wife and husband, but for example with respect to other family members who were expected to provide unpaid work, as was the case for mothers and mothers-in-law in their widowhood. According to the law, when the husband died, the dowry had to be returned to the widow by the husband's heir(s); from that time on, she had the right to freely manage and utilise it14. A widow could decide to invest her dowry in the child's family business and, precisely for this reason, (as was also the case for wives), she could not be considered only an unpaid labour force. When the agreement of collaboration was formalised by a notarial deed, benefits and advantages that she received for her work and investment were explicit, even if this did not lead to a salary. On the contrary, thanks to her dowry, she could negotiate economic profit and some kind of help for their everyday life in the future. I will explain this specific mechanism in the case study of Angela Spilman, widow of the master shoemaker Gio Spilman since January $1761^{15}$. One year after the husband's death, she decided to join her daughter and son-in-law, who had married in 1758. She decided to live with them and to work in their shop for the manufacturing of

13 Ibid., vol. 2774, f. 409r-v.

14 Studies about widowhood are numerous. For Italy see : (Palazzi, 1997); (Bellavitis, 2008). For other European countries: (Fauve-Chamoux, 1998); (Cavallo \& Warner, 1999); (Beauvalet-Boutouyrie, 2001); (Pellegrin \& Winn, 2003); (Lanza, 2009).

$15 \quad$ AST, sez. riun., Insinuazione di Torino, a. 1761, 1. 2, ff. 881r- 894v. 
stocking hats ${ }^{16}$. In April 1762, Angela signed an agreement with her daughter, Teresa, and her son-in-law, Gaspare Silvestro, master hat-maker and merchant. According to this, Angela invested 1400 livres of her dowry in Teresa and Gaspare's shop. The widow would participate as an associate and would benefit from one third of the total income. In addition, she would take part directly in the manufacturing and selling of hats. The widow, therefore, signed up for a double involvement in her son-in-law's family workshop: she provided a considerable sum as well as labour force - and presumably experience acquired in the husband's shoe-shop. Moreover, all these engagements were not taken on by the widow only in order to obtain economic benefits (though these were important too); but rather in order to negotiate for herself some kind of help in old age. This was explicitly declared; throughout her involvement the widow would receive "food, and clothes, in good health or in illness" 17. In this case, therefore, work and property together were used here as 'bargaining chips', allowing the widow to negotiate her well-being for the future. In addition, research on notarial deeds shows that Angela's economic participation was only one link in a longer chain of economic actions concerning Silvestro's workshop; indeed, the participation of the widow Angela Spilman was decided just after the alienation of the dowry of Teresa, Silvestro's wife. This took place in February 1762, when 800 livres of Teresa's dowry were invested in her husband's business. Two months later, Teresa's mother, Angela, also joined the business. It is worth noting that if the economic participation of the widow was clearly regulated, and reciprocal engagements and benefits were stipulated on both the sides in an official deed, this was not the case for the wife who invested her dowry in the familial business. In this case, we are able to infer her negotiation power by the means of clues.

\section{Women as independent entrepreneurs}

Another aspect offers evidence of the fact that Turinese married women belonging to artisanal and commercial professional groups cannot be considered as an unpaid labour force: their involvement in independent economic activities. Here again, these women were, at the same time, both workers and owners and for this reason they were not entitled to a salary. One of the most important achievements of recent research on female work was to complicate, and even call into question, the notion of "family business" as a coherent and mono-oriented

$16 \quad$ Ibid., a. $1763,1.5$, ff. $47 r-48 v$.

$17 \quad$ Ibid. 
economic activity, involving all the members of the household. Studying depositions given by female witnesses in the London church courts between 1695-1725, Peter Earle found that "it was unusual for husband and wife to work together at the same trade" (Earle, 1989, p. 338). Indeed, only 26 percent of the 256 employed wives stated that they worked with their husband. Similarly, Amy Louise Erickson has pointed out that in eighteenth century London "only a minority of couples worked together in the same or a related occupation, and these tended to be in entrepreneurial retail or craft work" (Erickson, 2008, p. 269). These percentages offer evidence of the fact that not all wives worked in a family business officially belonging to the male head of the family. Within this same perspective, recent scholarship which has focused on female entrepreneurship, has shown that in several social and economic contexts, a wife's working activity could be an autonomous and independent experience. (Erickson, 2008; Van Den Heuvel, 2008; Van Den Heuvel \& Van Nederveen Meerkerk, 2008; Bellavitis \& Guzzetti, 2012)18. Of course, this does not imply that, because of their job, wives achieved emancipation or some kind of personal fulfilment; their work was performed within the framework of the household economy and was finalised to ensure the survival of the family. Nevertheless, they could run successful businesses, thus gaining an awareness of the importance and expansion of their activity in the labour market.

These same female professional patterns have been found also in pre-industrial Turin. Here the percentage of couples sharing the same trade was close to those calculated for other European areas. According to the population census of 1802, 48 percent of the couples shared the same activity, i.e. 611 couples out of the 1270 couples who practiced a profession 19. These data are confirmed by the registers of the applicants to the Ospedale di Carità, the most important charitable institution in the city (Cavallo, 1990, 1995). These registers, in fact, show that only a quarter of couples, which amounted to 903 out of the 3757 households, were involved in the same profession20. Wives could decide to invest their dowry in a shop or business, and run it independently from the husband's activity. In some cases, the dowry itself was composed of tools and shop furniture. For example, in 1765 Teresa Moda brought to her marriage a dowry of more than 980 livres. Out of this sum, only 200 livres were paid in

\footnotetext{
18 On independent business of unmarried women see: (Sharpe, 1999).

19 Number of couples for whom the job of the husband and of the wife is known.

$20 \quad$ See footnote 19.
} 
money while the rest comprised the tools she used for her work as seamstress 21 . Similarly, according to the endowment act of Margherita Garnera which was stipulated in 1774, the dowry, which amounted to 300 livres, was composed of fancy goods and haberdashery that she sold in her shop22.

Further evidence of the presence of women in independent activities is provided by the registers of the taffeta weavers. In 1754, a royal edict issued by Charles Emanuel allowed women to join the taffeta weavers' guild, a branch of the powerful silk weavers guild. Their applications were collected in two registers which cover the period between 1754 and 1795 and are preserved in the archives of the Consolato di Commercio (the Turin civil court charged with monitoring work and trade). During this period, 82 women obtained the mastery: their applications, which were followed by regular updates on the status of their businesses, are a rich source of information which enables us to track their professional paths. These women managed thriving activities, owned looms (and sometimes a shop) and regularly took on apprentices. Anna Barilio, for example, was received in the guild in 187023. Ten years later her business flourished : in 1790 in fact, at the age of 38, she declared a capital of 1000 livres and one female apprentices, Caterina Damilano24 while in 1791 she obtained the right to produce and sell other kind of silk clothes, since the guild inspectors stated that her activity was prosperous and benefitted from credit and a good reputation25. Two other cases show a similar path towards prosperity: in 1791, three years after her admission to the guild, Margherita Borgnetta started to produce and sell several kinds of silk cloths in addition to taffeta fabrics26, while in 1796, Angelica Corte, who had joined the guild in 1794, enlarged her business and obtained the permission to add a second loom, since with only one loom she "would not be able to fulfil all the orders she received from silk merchants"27.

Cross-reference between the name of the female taffeta weavers and the population census of 1802 reveals the ambiguity of the wives' independent activities and suggests that in some cases, they were part of a mixed household economy in which an explicit distinction between the family business and the wife's activity is difficult to make. This means that

$21 \quad$ AST, sez. riun., Insinuazione di Torino, a. 1765, 1. 3, 1167r-1168v.

22 Ibid., a. 1774, 1. 4, ff. 1459r-1460v.

23 Ibid., Consolato di Commercio, Registro dei Taffetieri, vol. 66, f.f. n.n.

24 Ibid., vol. 67, ff. 155r-159v.

25 Ibid., ff. $160 r-161 r$.

26 Ibid., ff. $107 r-110 v$.

27 Ibid., ff. $211 r-216 r$. 
households in which women were active in a family business and households in which women ran their own independent activity represent merely the opposing ends of a spectrum which encompassed a wide array of configurations. No clear-cut boundary existed between those women who worked independently, and who therefore benefitted financially from their autonomous activity, and those women who performed unpaid work: the economic and labour relationships between husband and wife were more blurred. The wife's activity could be complementary or related to the husband's trade, and, at least, wives could perform using devices and tools they owned at home. Angela Rossetti, for example, was a master taffeta weaver, responsible for the apprenticeship of Clara Baraglia, when she married Giovanni Antonio Motta, a silk sock-maker28. A similar pattern concerned the already cited Anna Barilio, mistress taffeta weaver, and wife of Filippo Ferro, a merchant in cloths, sheets, aprons, academic gowns and scarfs29. In both cases, the couple's professions were (apparently) different, but clearly related and therefore it is likely that these couples shared the same social and professional network of customers, creditors and debtors. Of course the crossreference reveals also situations in which economic and labour relationships between husband and wife were clearer. This was the case of couples sharing the same trade, such as Anna Maria Prudan, daughter of a master silk weaver and married to Gio Maurizio Cavaleris, himself a silk weaver30; or the case of Gioanna and Francesco Miroglio, both admitted to the taffeta weavers' guild between December 1779 and February 178031.

At the opposing end of the spectrum, other female taffeta weavers did not share their craft with their betrothed and continued practicing their trade after marriage: Maddalena Formica, for example, married a coachman who was at the king's service, and continued to work as taffeta weaver during her marital life32. Similarly, the already cited Margherita Borgnetta did not cease her activity when she married Vincenzo Mathieu, a shop assistant in a library33. In conclusion, with such a great variety of situations, the registers of the taffeta weavers provide further evidence of the fact that in the Turinese artisanal system, married women did not constitute an unpaid labour force.

Ibid., vol. 66, f.f. n.n.

Ibid.

Ibid., vol. 67, ff. 85r-91v.

Ibid., vol. 66, ff. n.n.

Ibid.

Ibid., vol. 67, ff. $107 r-110 v$. 


\section{Daughters as an unpaid labour force}

In the previous paragraphs I have concentrated on the roles of wives and widows showing that, when active as artisans, retailers and shopkeepers, these women cannot be considered as an unpaid labour force because of their dual condition as workers and owners. However, even among these professional groups, several young women - namely unmarried daughters - performed some kind of unpaid work. Generally speaking, children were an important working force in a family business. Evidence from poor relief institutions shows that children made their first steps into the labour market at about 7 years of age. The Ospedale di Carità, in fact, accepted children aged 7 and over, when they were initiated in a craft and put into apprenticeship. Moreover, the same institution considered children over 14 years of age capable of earning their living and thus as potential contributors to the household economy by supplementing the incomes of parents and helping younger brothers and sisters. Family and kin were undoubtedly two of the most important agents in the learning and training process of young girls (and boys) in pre-industrial societies. In addition, the kinship network could also take charge of orphans or children who belonged to families in need. They could integrate the child in the family workshop and train him/her in a trade. In March 1792, for example, Anna Maria Trepié left the Ospedale and was entrusted to her uncle, a silk weaver who owned a workshop, "in order to learn the trade ${ }^{34}$ while Anna Giacinta Lavicino, in October 1781, obtained the authorisation to be dismissed from the institution "to go to work with her uncle," a gauze-maker in Turin ${ }^{35}$.

The registers of the taffeta weavers supply evidence of the presence of daughters as unpaid labour force. From 1754 to 1795 , out of the 82 women admitted to the mastery, one quarter learned the trade and was trained within the family network36: 16 girls were daughters of master silk weavers, 5 girls learned the trade from their mothers, one learned from an aunt, one from a paternal uncle and one from her step-father. Moreover, these girls stated that they had worked for a long time with their parents or kin, more than the three years required by the guild statute and the royal edict as a condition in order to obtain the mastery.

\footnotetext{
$34 \quad$ ASCT, Ospedale di Carità, cat. VI, Libri delle informazioni per i ricoveri, vol. 47, f. 844.

35 Ibid., vol. 40, f. 33.

36 On female apprenticeship in pre-industrial Europe see: (Hanawalt, 1993); (Krausman Ben-Amos, 1994); (Béghin, 1996); (Bellavitis, 2006a, 2006b); (Crowston, 2005); (Erickson, 2011); (Martinat, 2011). For Turin see: (Cavallo, 2006).
} 
Maddalena Formica learned her trade when she was 10 years old, while she worked under the supervision of her father Maurizio, master silk weaver ${ }^{37}$. Similarly, Antonia Maria Lisa learned the secrets of the trade from her father Agostino for 12 years; while Francesca Torsengo spent 20 years working alongside her mother Caterina ${ }^{38}$. Girls were therefore trained by their parents and moreover, since they collaborated with them for such a long time, they took part in their full capacity in the activity of the workshop. It is thus evident that these girls, were an incontestable and crucial resource for the family business, since they ensured a concrete (and unpaid) contribution well beyond the years dedicated to training. Mothers running independent activities (even when related to their husband's trade) trained their daughters and took advantage of their unpaid labour. Thus, girls were an important unpaid labour force in their mothers' retail activity or workshop.

Of course, the daughters did not obtain a salary for their work, but, similarly to married women, they could receive testamentary bequests. Teresa Giró, for example, a taffeta weaver who spent more than 12 years working in her father's shop, achieved from her parent the right to be financially supported and to receive clothing, which was to be charged to his estate paid for by her brother, throughout her celibacy, since "with her everyday work and help she was always at the service of his parental house" 39 . Other cases show that these young women could inherit the family workshop or tools: as, for example, Margherita, Maria and Maddalena Manassier, button-makers and heirs of their father's business40. Instead, Caterina Mattalia, a button-maker married to a shoemaker, learned the craft from her mother and inherited the little stall that her parent owned which was situated under the cloister of the prince of Francavilla in Turin ("un botteghino sotto li portici della casa del principe di Francavilla")41.

Labour relationships between mothers and daughters became more complicated in a specific phase of the family life-cycle: i.e. when a daughter, upon taking a husband, left behind en elderly mother unable to perform autonomously her trade. It is in fact only when this particular circumstance was reached that daughters acquired some negotiation power, since only then they were able to leave the parental house and cease working for the family (or the

AST, sez. riun., Consolato di Commercio, Registro dei Taffetieri, vol. 66, ff. n.n.

Ibid.

Ibid., Insinuazione di Torino, a. 1761, 1. 8, ff. 1264v-1266r.

Ibid., a. 1764, 1. 4, ff. 1353r-v.

Ibid., Consolato di Commercio, Bottonaj, vol. 6, ff. n. n. 
mother's) business. In this case, the mother's shop or simply her labour devices and tools were promised and transferred to the daughter and therefore used as "bargaining chips". Indeed, this operation allowed the latter to negotiate for herself (and eventually for her husband) some kind of support.

In a recent study, Angela Groppi has shown that in Old Regime societies, family relationships were not always taken for granted (Groppi, 2010). In early modern Rome, the primacy of family solidarity over the collectivity was not a "natural" matter of fact, but rather a value which had to be vigorously reasserted by the institutions in charge of relief, in view of the fact that "sons and daughters have the duty to ensure the maintenance of their parents". The Roman Ospizio Apostolico, a charitable institution for elderly, denied admission to people who had a son or daughter able to provide for their care. The same principle was at the origin of the sentences of the Tribunale del Vicariato, an ecclesiastical court that, during the eighteenth century, very frequently forced unwilling offspring to pay maintenance (alimenta) to their parents. It is therefore clear that in a context in which "family solidarity" was not automatic, but had to be reaffirmed by the institutions, the mother was encouraged to use her property in order to negotiate some kind of assistance in her old age.

Particularly among artisans, these dynamics were based on the connection between work and property. I will analyse this specific pattern through the case of Felicita Audoli and her mother Maddalena, a mistress ribbon-maker in the Turinese guild. According to a model previously explained, in 1760 Maddalena invested her dowry in a workshop for manufacturing and selling ribbons. In her words, the business was successful and Felicita was trained and worked for many years alongside her mother. Maddalena yet established that her daughter's dowry be administered in looms and other tools pertaining to their craft. In April 1769 Felicita married Antonio Marenco but continued to live with her parents and to help in the ribbon workshop. Less than a year later, in January 1770, the couple decided to "split from their respective parents and in-laws" 42 and start their own economic activity. The artisan was at that time ready to sit for her mastery exam, while her husband provided 2200 livres to set up a shop. With their departure from the parental house, Felicita and her husband asserted their right to take advantage of their incomes and work, with the aim of achieving economic independence. Despite this, Felicita's parents, Francesco and Maddalena, did not agree with

$42 \quad$ Ibid., Insinuazione di Torino, a. 1770, 1. 3, ff. 39r-44v. 
the decision, since Francesco was not "able to gain his livelihood" because he was "out of work and affected by serious ailments", and Maddalena, now old in age, was no longer able "to continue running the workshop (...) without the help of Felicita who had been involved in it for some time". In order to avoid the departure, Maddalena and Francesco offered their daughter the usufruct of all the tools in their workshop, as well as the furniture in the house. These goods were given under condition that Felicita and her husband stayed and lived with them. Moreover, the couple was required to "maintain Mr. and Mrs. Audoli whether in good or ill health and provide them with food, clothes and medicines and all other things necessary for their livelihood". Finally, Felicita and her husband were also obliged to pay the house rent and "every other charge necessary for the decent sustenance of the family". Felicita and her husband would take advantage freely of the artisanal workshop, tools and professional network as well as of Maddalena and Francesco's house, while the parents would receive from her some kind of help in their old age. This case is revealed thanks to a very loquacious notarial deed, but it is likely that similar agreements existed in numerous families, for individuals did not always resort to a notarial contract to establish these conditions, but they could very easily arrange verbal or written informal agreements of which remain no trace in the archives.

\section{Conclusions}

The aims of this paper were to investigate and discuss the role of the work performed by women in family shops in eighteenth-century Turin as well as to inquire into the reliability of the notion of unpaid work established by Delphy and Leonard (1992). According to their research, unpaid work refers to the direct and informal contribution of family members in workshops, retails, farms or other family businesses and is based on the predominance of the head of the household over his wife and children. The former owned their work as well as its product while the latter did not have right to a wage.

In pre-industrial Turin, the work performed by the kindred and family members was essential in the workshop system. This is well demonstrated by the activities of females within the family economy, even though married women and daughters working in the family business were clearly under-recorded - or not at all officially recorded - in sources, as the 1792 workshop census indeed demonstrates. Furthermore, in this paper I argue that the notion 
of unpaid work established by traditional scholarship is only partially pertinent among artisanal and commercial groups in preindustrial Turin and Italy in general, for whether this notion can be applied depends on the position of each member within the household. This paper, in fact, shows that daughters were an unpaid labour force in the family business or in their mother's independent activities. Yet, when it comes to wives and widows, the notion that assimilates their work to unpaid labour has to be mitigated, in view of them being both workers and owners at the same time. In Turin this was possible because upon marriage, as in other areas that followed Roman law, the bride brought into the new household a dowry that she invested in the family business or in an "independent" (or complementary) activity. Even though the husband officially retained the right to manage the dowry during their marital life, the wife never lost claims over its ownership. Moreover, at the husband's death, the dowry had to be returned to the widow by the husband's heir(s) and from that time on, she had the right to freely manage and employ it. Precisely because female work and property were intimately connected, when speaking of the middle and lower classes the notion that women whether wives or widows - have to be considered as an unpaid force is not applicable to the Turinese case. According to this perspective, female property affected the labour relationships between the members of the family. Owing to their dual status as workers and owners, wives and widows had bargaining power. Since their economic contribution was based on an intricate mixture of work and personal property, they could benefit from more than modicum of decisional power with regards to their relationship with the head of the household and could negotiate with their children and in-laws some kind of help and care for the future.

Of course, these findings do not call into question the fact that wives and widows worked hard and, in addition to the work related to their trade, they also performed some kind of unpaid work which comprised domestic chores and care for their children and for the ill or the elderly. Nor does this paper claim that female unpaid work did not exist. Rather, it suggests that it was typical of a specific phase of a woman's life cycle (it mostly concerned the young and unmarried) and that, marriage was a watershed since it enabled women to acquire a dowry, thus becoming owners in their full right. Women therefore could escape labour exploitation precisely by linking their property to the economic activity in which they were involved as workers. 


\section{References :}

Addabbo, T., Arrizabalaga, M.-P., Borderías, C., \& Owens, A. (Eds.) (2010). Gender Inequalities, Households and the Production of Well-Being in Modern Europe. Farnham : Ashgate

Agarwal, B. (1994). A field of one's own : gender and land rights in South Asia. Cambridge : Cambridge University Press

Ago, R . (1995). Ruoli familiari e statuto giuridico [Familiy roles and juridical statute]. Quaderni Storici, 88, 111-133

Ago, R. (1996). Oltre la dote. I beni femminili [Beyond the dowry. Female assets and property]. In A. Groppi (Ed.), Il lavoro delle donne [The women's work], (pp. 164-182). Rome-Bari : Laterza

Ago, R. (1998). Economia barocca. Mercato e istituzioni nella Roma del Seicento [Baroque economy. Market and institutions in seventeenth-century Rome]. Rome : Donzelli

Ago, R. (2001). La costruzione dell'identità maschile: una competizione tra uomini [The contruction of male identity : a competition between men]. In A. Arru (Ed.), La costruzione dell'identità maschile nell'età moderna e contemporanea [The construction of male identity in early modern and contemporary age](pp. 17-30). Rome : Biblink

Ago, R., \& Borello, B. (Eds.) (2008). Famiglie. Circolazione di beni, circuiti di affetti in età moderna [Families. Exchange of goods and networks of affection in early modern period]. Rome : Viella

Beauvalet-Boutouyrie, S. (2001). Être veuve sous l'Ancien Régime [Widows in Old Regime society]. Paris : Belin 
Béghin, C. (1996). Donneuses d'ouvrages, apprenties et salariées au XIV et $X^{\mathrm{e}} \mathrm{V}^{\mathrm{e}}$ siècles dans les sociétés urbaines languedociennes [Mistresses, apprentices and wage-earners in $14^{\text {th }}$ and $15^{\text {th }}$ centuries in urban societies of Languedoc]. Clio. Histoire, femmes, société, 3, 31-54

Bellavitis, A. (2006a). Le travail des femmes dans les contrats d'apprentissage de la Giustizia vecchia (Venise, $\mathrm{XVI}^{\mathrm{e}}$ siècle) [Women work and apprenticeship agreements at the Giustizia Vecchia court (Venice, $16^{\text {th }}$ century)]. In I. Chabot, J. Hayez, \& D. Lett (Eds.), La famille, les femmes et le quotidien (XIV -XVIII siècle). Textes offerts à Christiane Klapisch-Zuber [Family, women and domestic life (14 $14^{\text {th }} 18^{\text {th }}$ centuries). Papers in honour of Christiane Klapisch-Zuber] (pp. 181-195). Paris : Publications de la Sorbonne

Bellavitis, A. (2006b). Genres, métiers, apprentissages dans trois villes italiennes à l'époque moderne [Gender, jobs, apprenticeship in three Italian cities in Early Modern period]. Histoire Urbaine, 15, 5-12

Bellavitis, A. (2008). Famille, genre, transmission à Venise au XVI siècle [Family, gender, transmission in sixteenth-century Venice]. Rome : École Française de Rome

Bellavitis, A., \& Guzzetti L. (Eds.) (2012), Donne, lavoro, economia a Venezia e in terraferma tra medioevo ed età moderna [Women, work, economy in Venice and in terraferma between Medieval and Early Modern age]. Archivio Veneto, 3

Calvi, G., \& Chabot, I. (Eds.) (1998). Le ricchezze delle donne. Diritti patrimoniali e poteri familiari in Italia (XIII-XIX secc.) [Female assets. Property rights and family power in Italy $\left(13^{\text {th }}-19^{\text {th }}\right.$ centuries $\left.)\right]$. Turin : Rosenberg \& Sellier

Castiglioni, P. (1862). Relazione generale con una introduzione storica sopra i censimenti delle popolazioni italiane dai tempi antichi sino all'anno 1860 [Collective report with an historical introduction about the censuses of the Italian populations from ancient times until 1860]. Turin : Stamperia Reale 
Cavallo, S. (1990). Patterns of poor relief and patterns of poverty in eighteenth-century Italy: the evidence of the Turin Ospedale di Carità. Continuity and Change, 5, 65-98

Cavallo, S. (1995). Charity and power in early modern Italy. Benefactors and their motives in Turin, 1541-1789. Cambridge : Cambridge University Press

Cavallo, S. (2006). Métiers apparentés : barbiers-chirurgiens et artisans du corps à Turin (XVII - XVIII ${ }^{\mathrm{e}}$ siècle) [Related jobs : barber-surgeons and artisans of the body in Turin $\left(17^{\text {th }}\right.$ $18^{\text {th }}$ centuries) $]$. Histoire Urbaine, 15, 27-48

Cavallo, S., \& Warner, L. (Eds.) (1999). Widowhood in Medieval and Early Modern Europe. London-New York : Longman

Chicco, G. (1995). La seta in Piemonte (1650-1800). Un sistema industrial d'ancien régime [Silk in Piedmont (1650-1800). An Old Regime manufacturing system]. Milan : F. Angeli

Chicco, G. (2002). Alla periferia della moda. Mercanti e tessitori nel Settecento [At the periphery of the fashion system : Merchants and weavers in the eighteenth-century]. In G. Ricuperati (Ed.), Storia di Torino. La città fra crisi e ripresa (1630-1730) [A history of Turin: the city between crises and recovery (1630-1730)], vol. IV, (pp. 911-938). Turin: Einaudi

Clark, A. (1919). Working life of the women in the seventeenth century. London : Routledge

Crowston, C. H. (2005). L'apprentissage hors corporations. Les formations professionnelles alternatives à Paris sous l'Ancien Régime [Apprenticeship out of guilds. Alternative skilled learning patterns in Old Regime Paris]. Annales HSS, mars-avril, 2, 409-441

D’Amelia, M. (1993). «Una lettera a settimana ». Geronima Varalli Malatesta al signor fratello 1575-1622 [«A letter once a week ». Geronima Varalli Malatesta to her brother 15751622]. Quaderni Storici, 83, 381-413 
Delphy, Ch. (1998). L'ennemi principal. 1, Économie politique du patriarcat [The main ennemy. 1, Political economy of patriarchy]. Paris : Éd. Syllepse

Delphy Ch., \& Leonard, D. (1992). Familiar exploitation: a new analysis of marriage in contemporary western societies. Cambridge : Polity Press

Earle, P. (1989). The female labour market in London in the late seventeenth ad early eighteenth centuries. Economic History Review, XLII(3), 305-327

Erickson, L. A. (2008). Married Women's occupations in eighteenth-century London. Continuity and Change, 23(2), 267-307

Erickson, L. A. (2011). Eleanor Mosley and other milliners in the City of London Companies 1700-1750. History Workshop Journal, 71, 147-172

Fauve-Chamoux, A. (1998). Vedove di città e vedove di campagna nella Francia preindustriale: aggregato domestico, trasmissione e strategie familiari di sopravvivenza [Widows in the city and widows in the countryside in preindustrial France: households, transmission and familial strategies for survival]. Quaderni Storici, 98, 301-332

Fauve-Chamoux, A. (2001). Continuity and change among Rhemish proletariat : preindustrial textile work in family perspective. The History of the Family, 6, 167-185

Fontaine, L. (2008). L'économie morale. Pauvreté, crédit et confiance dans l'Europe préindustrielle [The moral economy. Poverty, credit and trust in preindustrial Europe]. Paris : Gallimard

Frigo, D. (1985). Il padre di famiglia: governo della casa e governo civile nella tradizione dell"Economica' tra Cinque e Seicento [The pater familias: management of the house and public government in the tradition of the 'Economica' between 1500 and 1600]. Rome: Bulzoni 
Fubini Leuzzi, M. (1999). «Condurre a onore ». Famiglia, matrimonio e assistenza dotale a Firenze in Età Moderna [« Condurre a onore ». Family, marriage and support for dowry in Early Modern Florence]. Florence : Olschki Editore

Groppi, A. (1996). Lavoro e proprietà delle donne in età moderna [Female work and property in early modern age]. In A. Groppi (Ed.), Il lavoro delle donne [Women's work] (pp. 119163). Rome-Bari : Laterza

Groppi, A. (2002). A matter of fact rather than principle : women, work and property in papal Rome (eighteenth-nineteenth centuries). Journal of Modern Italian Studies, 7(1), 37-55

Groppi, A. (2010). Il welfare prima del welfare. Assistenza alla vecchiaia e solidarietà tra generazioni a Roma in età moderna [The welfare before the welfare system. Relief for elderly people and solidarity between generations in Early Modern Rome]. Rome : Viella

Hafter, D. (2003). Les veuves dans les corporations de Rouen sous l'Ancien Régime [Widows in guilds of Rouen in Old Regime]. In N. Pellegrin, \& C. H. Winn (Eds.), Veufs, Veuves, Veuvages dans la France d'Ancien Régime [Widowers, Widows, Widowhood in Old Regime France] (pp. 121-133). Paris : Honoré Champion

Hafter, D. (2007). Women at work in Preindustrial France. University Park, Pennsylvania : The Pennsylvania State University Press

Hanawalt, B. (1986). Peasant Women's Contribution to the Home Economy in Late Medieval England. In B. A. Hanawalt (Ed.), Women and Work in Preindustrial Europe (pp. 3-19). Bloomington : Indiana University Press

Hanawalt, B. (1993). Growing up in Medieval London. The experience of childhood in history. New York-Oxford :Oxford University Press 
Humphries, J., \& Sarasúa C. (2012). Off the record. Reconstructing women's labor force participation in the European past. Feminist Economics, 18(4), 39-67

Klapisch-Zuber, Ch. (1990). Le complexe de Griselda: dots et dons de mariage [The complex of Griselda : dowry and wedding gifts]. In Ch. Klapisch-Zuber (Ed.), La Maison et le nom. Stratégies et rituels dans l'Italie de la Renaissance [The Casa and the name. Strategies and rituals in Renaissance Italy] (pp.185-213). Paris : Ed. EHESS

Krausman Ben-Amos, I. (1994). Adolescence and youth in Early Modern England, New Haven-London : Yale University Press

Lanza, J. (2009). Les veuves dans les corporations parisiennes au XVIIIe siècle [Widows in guilds in Paris in eighteenth-century]. Revue d'Histoire Moderne et Contemporaine, 56(3), 92-122

Lumia, G. (1998). Mariti e mogli nei testamenti senesi di età moderna [Husbands' and Wives' Testaments in Early Modern Siena]. In G. Calvi, \& I. Chabot (Eds.), Le ricchezze delle donne. Diritti patrimoniali e poteri familiari in Italia (XIII-XIX secc.) [Female assets. Property rights and family power in Italy (1 $3^{\text {th }}-19^{\text {th }}$ centuries)] (pp. 43-63). Turin : Rosenberg \& Sellier

Martinat, M. (2011). Travail et apprentissage des femmes à Lyon au XVIII ${ }^{\mathrm{e}}$ siècle [Women's work and apprenticeship in eighteenth-century Lyon]. Mélanges de l'Ecole Française de Rome, Italie et Méditerranée MEFRIM, 123(1), 11-24

Musgrave, E. (1993). Women in the male world of work: the building industries of eighteenth-century Britanny. French History, 7(1), 30-52

Owen Hughes, D. (1975). Urban Growth and Family Structure in Medieval Genoa. Past and Present, 66(1), 3-28. 
Palazzi, M. (1997). Donne sole. Storia dell'altra faccia dell'Italia tra antico regime e società contemporanea [Lonely women. History of the other face of Italy between Old Regime and contemporary society]. Milan : Bruno Mondadori

Pene Vidari, G. S. (1980-81). Osservazioni sui rapporti patrimoniali fra coniugi nel Piemonte del sec. XVIII [Remarks on marital agreements in eighteenth-century Piedmont]. Rivista di Storia del Diritto Italiano, 54, 19-60.

Pene Vidari, G. S. (1983). Dote, famiglia e patrimonio fra dottrina e pratica in Piemonte [Dowry, family and assets between theory and practice in Piedmont]. In La famiglia e la vita quotidiana in Europa dal '400 al '600. Atti del colloquio, Milano 1-4 dicembre 1983 [Family and domestic life in Europe from 1400 to 1600. Proceedings of the workshop, Milan 1-4 December 1983] (pp. 109-121). Rome : Ed. Ministero Beni Culturali.

Pellegrin, N., \& Winn, C. H., (Eds.) (2003), Veufs, Veuves, Veuvages dans la France d'Ancien Régime [Widowers, Widows, Widowhood in Old Regime France]. Paris : Honoré Champion

Philipps, L. (2008). Silent partners: the role of unpaid market labor in families. Feminist Economics, 14(2), 37-57

Sharpe, P. (1999). Dealing with love. The ambiguous independence of the single woman in Early Modern England. Gender \& History, 11(2), 209-232

Sen, A. (1999). Development as freedom. Oxford : Oxford University Press

Scardozzi, M. (1998). Tra due codici: i contratti dotali nella Toscana preunitaria [Between two codes : endowment agreements in Tuscany before unification]. In G. Calvi, \& I. Chabot (Eds.), Le ricchezze delle donne. Diritti patrimoniali e poteri familiari in Italia (XIII-XIX secc.) [Female assets. Property rights and family power in Italy $\left(13^{\text {th }}-19^{\text {th }}\right.$ centuries)] (pp. 95120). Turin : Rosenberg \& Sellier. 
Simonton, D. (2005). Claiming their Place in the Corporate Community: Womens's Identity in Eighteenth-Century Towns. In I. Baudino, J. Carré, \& C. Rèvauger (Eds.), The Invisible Women. Aspects of Women's Work in Eighteenth-Century Britain (pp. 101-116). Aldershot: Ashgate

Van Den Heuvel, D., (2008). Partners in marriage and business? Guilds and the family economy in urban food markets in the Dutch Republic. Continuity and Change, 23(2), 217236

Van Den Heuvel, D., \& Van Nederveen Meerkerk, E. (2008). Introduction: partners in business. Spousal cooperation in trades in early modern England and the Dutch Republic. Continuity and Change, 23(2), 209-216

Zemon Davis, N. (1986). Women in Crafts in Sixteenth-century Lyon. In B. Hanawalt (Ed.), Women and work in preindustrial Europe (pp. 167-197). Bloomington, Indianapolis: Indiana University Press

Zucca Micheletto, B. (2013). Reconsidering female labor force rates using new sources in eighteenth-century Turin. Feminist Economics, 19(4), 200-223

Zucca Micheletto, B. (2014). Travail et propriété des femmes en temps de crise (Turin, XVIII siècle) [Women work and property in hard times (Turin, $18^{\text {th }}$ century)]. Mont-Saint-Aignan, France : Presses Universitaires de Rouen et du Havre 